\title{
Limiting costs or correcting market failures? Finance ministries and frame alignment in UN climate finance negotiations
}

\author{
Jakob Skovgaard ${ }^{1}$
}

Accepted: 13 December 2016/Published online: 3 January 2017

(C) The Author(s) 2017. This article is published with open access at Springerlink.com

\begin{abstract}
Finance ministries are increasingly involved in UN climate finance negotiations, yet this development received very limited attention in the literature on climate finance or climate negotiations. It is not obvious from the literature on bureaucratic politics how these ministries will position themselves on climate finance: they may frame climate finance as expenditure to be limited or as an instrument for correcting the market failure of climate change. This paper investigates which frames have characterised the positions of finance ministries on key issues in the climate finance negotiations, and whether the use of a given frame corresponds to particular factors. Case studies of Denmark, India, Indonesia and the USA based on official documents and interviews show that the position of each finance ministry is generally consistent with one particular frame. The Indonesian and Danish finance ministries predominantly framed climate finance as a way of correcting a market failure. The Indian Ministry of Finance emphasised Common but Differentiated Responsibilities, which fits with the budget frame. The US Treasury's position similarly fits with the budget frame while sharing elements of the market failure frame. Finance ministries that had the lead on climate finance were more likely follow the budget frame. The use of both frames cuts across the divide between industrialised and emerging economies. With the exception of the USA, left- and right-wing governments were equally likely to adopt either frame. These findings indicate that strengthening finance ministry forums built around the market failure frame can be a way of reducing norm fragmentation.
\end{abstract}

Keywords Climate finance - Climate change $\cdot$ UNFCCC negotiations · Bureaucratic politics $\cdot$ Finance ministries

\section{Abbreviations \\ CBDR Common but Differentiated Responsibilities \\ COP Conference of the Parties}

Jakob Skovgaard

jakob.skovgaard@svet.lu.se

1 Department of Political Science, Lund University, P.O. Box 52, 22100 Lund, Sweden 


$\begin{array}{ll}\text { DNPI } & \text { Indonesian National Council on Climate Change } \\ \text { GDP } & \text { Gross domestic product } \\ \text { MDBs } & \text { Multilateral development banks } \\ \text { UNFCCC } & \text { United Nations Framework Convention on Climate Change }\end{array}$

\section{Introduction}

A crucial aspect of the fragmented climate finance system is the diversity of positions held by countries in United Nations Framework Convention on Climate Change (UNFCCC) negotiations on climate finance (see special issue Editorial). In addition to the difference of positions, existing literature has demonstrated the importance of bureaucratic politics for negotiation positions (Kaarbo 1998; Downie 2014), including the role of finance ministries (Skovgaard 2015). Finance ministries are increasingly involved in the climate finance system, particularly in the UN climate finance negotiations. Yet, there is nothing preordained about the role that finance ministries play in this context, since they may equally well frame climate policy as tool to correct a market failure or as an expenditure to be limited (Skovgaard 2012). In terms of climate finance negotiation positions, the former frame ("the budget frame") arguably implies limiting domestic expenditure on climate finance and-in the case of developing countries ${ }^{1}$ - maximising climate finance from industrialised countries. The latter frame ("the market failure frame") implies a willingness to provide climate finance, a preference for channelling climate finance through multilateral development banks (MDBs), and an emphasis on efficiency.

How the position of finance ministries is framed has significant repercussions for the climate finance system, particularly regarding the fragmentation of norms and institutions across the system. ${ }^{2}$ On the one hand, convergence between finance ministries from different countries around the market failure frame could reduce norm fragmentation within the climate system, since the frame would support a set of transnationally shared norms emphasising collective action. Yet, given that convergence around the market failure frame would be shared transnationally between finance ministries but not necessarily within the individual governments (see Skovgaard 2012), this scenario could lead to institutional fragmentation between institutions supported not so much by different countries as by different ministries. On the other hand, convergence around the budget frame could constitute a domestic cause of increased norm fragmentation, since the finance ministries would pull their national negotiation positions in the direction of less cooperative, more self-interested stances. Arguably, in case of convergence around the budget frame, finance ministries support or oppose norms depending on whether they would make them better off fiscally, e.g. Common but Differentiated Responsibilities (CBDR) being promoted by developing countries (see special issue Editorial). ${ }^{3}$ Thus, frame convergence could cause increased norm fragmentation and possibly also institutional fragmentation (since finance ministries would support the institutions that improve their fiscal situation) along the

\footnotetext{
${ }_{1}$ For the purposes of this article, developing countries are understood as those not listed in Annex II to the UN Framework Convention on Climate Change, and industrialised countries are understood as those listed in Annex II.

2 On the definition and scope of this system, and on the concept of normative and institutional fragmentation, see the special issue Editorial.

${ }^{3}$ CBDR can also make sense from an equity perspective.
} 
industrialised/emerging country fault line. In a situation where the market failure frame characterises the position of some finance ministries and the budget frame that of others, the lines along which the finance ministries converge and diverge are crucial, e.g. if developing finance ministries subscribe to one frame and industrialised finance ministries to another.

Furthermore, in some countries, the finance ministry has the overarching (or lead) responsibility for the climate finance negotiations, while in other countries the lead belongs to other ministries, particularly environment or foreign ministries.

Consequently, the present article will answer the following research questions:

1. Which frames have characterised finance ministries' positions in UN climate finance negotiations?

2. Do particular frames correspond to the finance ministry having the lead on climate finance or to economic or political characteristics of the state?

In order to answer the first question, the paper identifies which frames best describe the finance ministry's position regarding climate finance negotiations, or the position it thinks the country should pursue in the negotiations. The focus will be on the above-mentioned market failure or budget frames. The second question is answered by analysing whether subscription to particular frames corresponds to the finance ministry having the lead, to its belonging to an industrialised or developing economy or to its being part of a left- or rightwing government.

Finance ministries' roles as both veto actors and economic actors make them particularly important regarding these negotiation positions. The former role grants them power over expenditure decisions, while the latter role means that they prioritise economic objectives over environmental ones and assess policies in terms of economic impact. Focusing on the role of finance ministries regarding the USA, Indian, Indonesian and Danish negotiation positions on climate finance since 2007 allows the possibility of exploring differences between countries. The countries have been selected in order to cover countries varying in terms of finance ministry lead on climate finance as well as on extrabureaucratic factors, namely being an industrialised or emerging economy and undergoing government change. ${ }^{4}$ From a finance ministry perspective, the most relevant aspects of the climate finance negotiations concern how much finance the industrialised countries should provide individually and as a group, through which channels climate finance should flow, and which principles should guide the allocation of funding.

The paper proceeds as follows: first, a theoretical framework is established, drawing on the literature on bureaucratic politics and on the role of frames within policy-making (Sect. 2). Subsequently, the issues in UNFCCC climate finance negotiations most pertinent to this paper are outlined (Sect. 3.1), as are the explanatory factors prevalent in the academic literature on climate finance (Sect. 3.2). In Sect. 4, a set of propositions regarding the position on the climate finance negotiations is established on the basis of the theoretical framework. Section 5 discusses the methodology including case selection. Finally, the theoretical framework is used to analyse the role of the budget and market failure frames in the cases of Denmark, India, Indonesia and the USA (Sects. 6.1-6.4) and the distribution of the frames between the countries (Sect. 6.5).

\footnotetext{
4 The paper focuses on emerging economies rather than developing countries in general since debates in the UNFCCC have focused on whether the former group should contribute climate finance (see below).
} 


\section{Theoretical framework: frames and finance ministries}

The literature on the intragovernmental dynamics of negotiations provides a useful framework for studying the role of finance ministries (Moravcsik 1998; see Downie 2014; Raustiala and Victor 2004: 280, for examples of such approaches within climate governance). Often this literature draws on the bureaucratic politics literature, according to which bureaucratic entities have different interests and-according to several scholarsalso different interpretive perspectives on issues (Allison and Zellikow 1999; Kaarbo 1998).

Schön and Rein (1994: 23-29) argue that policy positions rest on frames, i.e. underlying structures of belief, perception and appreciation. These structures emphasise different features and relations of an issue as being particularly relevant. A frame has implications for which actions it is logical to employ, what their consequences will be, and which actions are appropriate in a given situation (e.g. if the frame defines it as an economic issue rather than an environmental issue). It is important to distinguish between two understandings of the concept of a frame: first, frames as underlying structures of belief (Schön and Rein 1994), and second, the strategic use of frames by actors as devices to increase support for a particular measure (Pralle 2009). The use of a particular frame in the latter sense may or may not reflect the beliefs of the actor using the frame. The present paper will use "frame" in the former sense of an underlying structure of belief.

Arguably, the frames inherent in the climate finance positions of finance ministries are rooted in their two predominant roles. First, the role as "guardians of the budget" who protect the fiscal balance has received most scholarly attention (Wildavsky 1986; Kingdon 2003). Besides limiting expenditure, this role also emphasises-to a lesser degree-securing revenue (Wildavsky 1986). Finance ministries derive most of their power from this role, which consists of setting the levels of funds allocated to the different policy areas as part of the budgetary process, while ensuring that expenses do not exceed the established goals (Wildavsky 1986). All demands for new or increased funding-including for climate finance-must be approved by the finance ministry. According to this role, finance ministries view policy proposals through a cognitive lens which focuses on their impact on the state budget, and a normative lens which defines additional expenditure, especially inefficient expenditure, as undesirable.

Second, finance ministries' role as guarantors of long-term macroeconomic stability and growth; a role that may be as important as that of fiscal guardian. This role is based on ideas rooted in the training of finance ministry employees within neoclassical economics (Seabrooke 2011) which concern the efficiency of markets (Kanbur 2001) and which define economic costs to society rather than to the public budget as the problem.

The two roles may pull in the same direction (when expenditure is seen as hindering growth) as well as in opposite directions (when expenditure is seen as improving growth). An important difference is time horizon: guarding the budget entails focusing on budget items on next year's budget, while protecting macroeconomic stability entails focusing on developments often lasting decades.

The finance ministry having the lead on climate finance may also constitute an important aspect of its role regarding climate finance. The lead ministry chairs meetings on the issue, writes the first draft of negotiation texts and represents the country in the negotiations. This paper focuses on the lead as it constitutes the single most important aspect of the policy process: Having the lead exposes the finance ministry directly to the 
negotiations and confers upon the finance ministry the responsibility for achieving desirable outcomes in the negotiations.

\section{The climate finance negotiations}

\subsection{Key issues in the climate finance negotiations}

In order to study finance ministries' positions, it is necessary to focus on the most pertinent issues (to finance ministries) in the climate finance negotiations:

1. Which countries should contribute climate finance and how much?

2. Through which channels should climate finance flow?

3. Which principles should determine the allocation of climate finance?

Regarding the first issue, the negotiations have focused on collective and individual targets for industrialised countries and the scope of the group of contributing countries. At the Fifteenth Conference of the Parties (COP15), the US $\$ 100$ billion target was adopted. The G77 + China negotiating group had in the preceding negotiations proposed a target of $1-1.5 \%$ of industrialised countries' gross domestic product (GDP), while several industrialised countries were opposed to any quantified targets at all, although not to providing climate finance (Bailer and Weiler 2015: 54-55). The negotiations have also focused on whether there should be a burden-sharing formula (e.g. based on GDP or emissions) determining individual countries' contributions and whether emerging economies should contribute in addition to the existing group of industrialised countries. The USA has been particularly opposed to a burden-sharing formula, while developing countries have opposed any measures to expand the group of contributors apart from encouraging - in the words of the Paris Agreement_- "other Parties [...] to provide or continue to provide such support voluntarily" (UNFCCC 2015: Decision 1/CP.21, Article 9(2)). In order to avoid "watering down" of industrialised countries' commitments, several developing countries have insisted that there be strict requirements for measurement, reporting and verification of climate finance, that climate finance be "new and additional" to development aid (UNFCCC 1992: Article 4(3); see also special issue Editorial), and that private finance not replace public finance. At the same time, several industrialised countries have argued that such requirements could hinder utilising synergies between climate finance and development aid as well as the leveraging of private finance, both of which can improve the efficiency of climate finance (see Hall; Pauw, this issue).

The second issue concerns whether climate finance should flow through UN funds, MDBs or bilateral channels. Industrialised countries prevail within bilateral and multilateral development institutions compared to the UN climate institutions, in which developing countries exert greater control (Moore 2012: 36-38; Ciplet et al. 2013). The vagueness of the finance commitments in the Copenhagen Accord, Cancún Agreements and Paris Agreement grants industrialised countries significant discretion over these decisions, including how much to allocate to the UNFCCC Green Climate Fund (UNFCCC 2009, 2010, 2015). ${ }^{5}$

\footnotetext{
5 Although the industrialised countries as a group are obliged to channel a "significant" proportion of their adaptation finance through the GCF (UNFCCC 2009: Decision 2/CP.15, paragraph 8; 2010: Decision 1/CP.16, paragraph 100).
} 
The third issue concerns principles for the allocation of climate finance, of which the most pertinent for this paper are efficiency and equity (see e.g. Persson and Remling 2014; Stadelmann et al. 2014). Efficiency refers to the "allocation of public resources such that net social benefits are maximised" (Persson and Remling 2014: 489). Thus, efficient climate finance is spent where it provides the greatest amount of mitigation or adaptation ${ }^{6}$ for a given amount of money, which generally means (at least in the case of mitigation) focusing on emerging economies rather than the least developed countries.

Equity implies that the burden of mitigating and adapting to climate change should be distributed in a way that is fair, with normative principles such as CBDR and historical responsibility determining what is meant by equitable (Hof et al. 2011; Dellink et al. 2009). CBDR - a principled enshrined in the UNFCCC (1992, Article 3(1)) -implies that the industrialised countries shall take on a larger burden than developing countries (see special issue Editorial), and that-according to inter alia developing countries-developing countries are entitled to finance for mitigation and adaptation with few conditions on how funding is used (possibly downplaying efficiency).

\subsection{Factors influencing national positions on climate finance}

The academic literature on climate finance has mainly focused on issues of generation and allocation (see the contributions to Haites 2014; Michaelowa 2012; Betzold and Weiler, this issue) rather than on UN climate finance negotiations. However, Bailer and Weiler (2015) studied the impact of different factors (vulnerability, power, democracy, fossil fuel sector, domestic environmental standards and membership of environmental organizations) on negotiating positions concerning mitigation finance and emissions reduction targets. On a related note, the literature explaining the provision and allocation of climate finance has studied the impact of factors such as: the environmental orientation of the government or of the public in the donor/provider country (Michaelowa and Michaelowa 2011), level of income, carbon dioxide emissions or quality of government (for all three factors, see Halimanjaya and Papyrakis 2012), and the involvement of different government ministries or agencies (Pickering et al. 2015).

The foreign policy literature has demonstrated the importance of bureaucratic politics for negotiation positions (Kaarbo 1998; Allison and Zellikow 1999), including the role of finance ministries in defining an EU position on climate finance (Skovgaard 2015), and in the allocation of climate finance (Pickering et al. 2015). Since climate finance does not affect domestic vested interests to the extent that mitigation commitments do (Bailer and Weiler 2015: 60-62), finance ministries have (all things equal) better possibilities for influencing national negotiating positions than in the case of mitigation commitments (for a comparative study of the domestic drivers of mitigation policy and negotiation positions, see Harrison and Sundstrom 2007).

\section{Operationalising the theoretical framework}

The two roles of finance ministries translate into two finance ministerial framings of climate policy (Skovgaard 2012: 3-4). According to the budget frame, climate policy is an expenditure that should be limited. However, according to the market failure frame,

\footnotetext{
6 This paper mainly focuses on mitigation finance due to its predominant share of climate finance (see special issue Editorial) and its greater importance to finance ministries (see below).
} 
climate change constitutes a market failure (more specifically a negative externality) that should be corrected in order to create a long-term optimal outcome, even if it requires significant public expenditure. The market failure frame draws on neoclassical environmental economics (see Stern et al. 2013). ${ }^{7}$ The cognitive elements of this frame imply that environmental outcomes are measured in terms of economic costs and benefits, while actors are assumed to create optimal outcomes if given the right incentives. The normative elements imply that climate change is problematic because it produces an outcome that is less than economically optimal for (domestic) society as a whole (Jacobs 1997: 371-372).

The two frames are ideal-types, and often policy involves more than one of them but nonetheless clusters around one frame rather than the other. The frames may clash when climate policies require expenditure. In order to understand the role of finance ministries, these two frames are essential, and adherence to specific principles (e.g. CBDR) will be understood in the light of how such adherence fits with the two frames. ${ }^{8}$

The analysis will explore whether the position of a finance ministry can be characterised in terms of either the budget or market failure frame by testing whether the ministry's positions on key issues in the negotiations were consistent with one of the two frames (see Table 1). The relationship between frames and priorities has been established on the basis of their logical "fit", i.e. whether the specific priority plausibly follows from the assumptions contained in one frame rather than the other. The frames do not necessarily imply a distinct position regarding every priority, e.g. in the case of industrialised countries the budget frame does not imply particular preferences regarding channels or allocation principles.

Finance targets may be the issue on which the difference is most pronounced. Arguably, the market failure frame (in the cases of industrialised and emerging economies) implies a preference for a high collective target and willingness to provide climate finance on the condition that other countries also contribute finance or act against climate change. It is important that emerging economies also contribute climate finance and/or significant selffinanced domestic action in order to address climate change effectively and thus promote long-term economic stability. This willingness to contribute climate finance mainly concerns mitigation finance, since adaptation finance does not as such address the market failure aspect of climate change. The market failure frame ideally recommends global carbon pricing internalising the externality of climate change (Stern 2006). However, given that such a solution is politically unrealistic, using climate finance to cover parts of the additional costs of mitigation and possibly also compensate for adaptation is the preferred solution. The budget frame implies that industrialised countries will prefer to avoid or minimise collective and especially individual targets, while emerging economies will prefer to avoid climate finance commitments at the same time as they seek to maximise the commitments of industrialised countries, as this can have positive impact on state revenue. Hence, in the case of emerging economies, the key difference between the market failure and the budget frame is not in the size of the global target or in the desire to maximise finance from industrialised countries, but in which countries should contribute climate finance.

Concerning channels for finance, the expectation is that differences in position will be less pronounced across the two frames. The market failure frame implies a pronounced preference across industrialised and emerging economies for MDBs, due to the economic

\footnotetext{
7 Whereas the budget frame is not rooted in a specific theoretical paradigm.

8 This does not explain why the finance ministry adopt positions consistent with a particular frame: a finance ministry may very well adopt particular positions because they are considered normatively right.
} 
Table 1 Finance ministry frames and priorities in the negotiations

\begin{tabular}{|c|c|c|}
\hline \multirow[t]{2}{*}{ Priorities } & \multicolumn{2}{|l|}{ Frames } \\
\hline & Market failure & Budget \\
\hline Targets & $\begin{array}{l}\text { Willingness to provide significant climate } \\
\text { finance on condition of concerted effort }\end{array}$ & $\begin{array}{l}\text { Minimise individual contribution } \\
\text { Emerging economies: maximise } \\
\text { contribution of industrialised countries }\end{array}$ \\
\hline Channels & MDBs & $\begin{array}{l}\text { Industrialised countries: bilateral, to a lesser } \\
\text { degree MDBs } \\
\text { Emerging economies: UNFCCC institutions }\end{array}$ \\
\hline $\begin{array}{l}\text { Allocation } \\
\text { principles }\end{array}$ & Efficiency & $\begin{array}{l}\text { Emerging economies: compatible with } \\
\text { CBDR and historical responsibility }\end{array}$ \\
\hline
\end{tabular}

outlook (similar to the market failure frame) of these development banks. In the case of industrialised countries, the two frames equally imply reluctance regarding UN institutions. The budget frame implies diverging positions between industrialised and emerging economies. In the case of industrialised country finance ministries, the budget frame implies a preference for bilateral channels and to a lesser degree MDBs, because these channels grant them more control and guarantees that fiduciary standards will be met. In the case of developing country finance ministries, the budget frame implies a preference for UN institutions in which they have more influence over the allocation of funds.

Concerning the principles for allocating climate finance, the market failure frame implies emphasis on efficiency, understood as maximising net social benefits on a global and long-term scale taking into account the net present value of future climate change. In the case of industrialised countries, the budget frame also implies an emphasis on efficiency understood as maximising the cost-effectiveness of mitigation finance, as mitigation, unlike adaptation, is perceived (by most scholars: see special issue Editorial) as a global public good. Yet, in emerging economies this frame implies reluctance to use efficiency as a principle for allocating climate finance. This is because efficiency would allow industrialised countries to minimise their contribution and create competition between developing countries over climate finance.

The roles of the two frames can be summed up in the following proposition:

Proposition 1 Finance ministries consistently adopt positions on priorities in negotiations that are consistent with one particular frame.

It is also worth exploring whether the use of the two frames by different finance ministries corresponds to different contextual factors. One such factor is having the lead, which means chairing intragovernmental policy processes, defining the national negotiation position and presenting this position in UNFCCC negotiations. Arguably, chairing the process would induce the finance ministry to adopt a "balanced" position and avoid positions radically different from those of other ministries. Furthermore, participating directly in the negotiations means that the finance ministry is directly exposed to the positions of other negotiators, and therefore possibly less likely to adopt positions it knows would isolate it in the negotiations, such as minimising its contribution to climate finance. Both aspects could make the finance ministry less likely to adopt positions aligned with the budget frame. 
Proposition 2a Finance ministries that have the lead on climate finance adopted positions on key issues more aligned with the market failure frame than the budget frame.

However, it is possible that the extra-bureaucratic factors of belonging to an emerging economy or industrialised country and to a left-wing or right-wing government matter for the finance ministry's framing. Regarding the former, it is likely that finance ministries will align along the industrialised/emerging economies divide, since this is the most salient divide in the UNFCCC climate negotiations.

Proposition $2 \mathbf{b}$ Finance ministries within the same country grouping are likely to share the same frame.

Finally, since right-wing governments tend to be less concerned with environmental issues (Michaelowa and Michaelowa 2011: 2014) and more concerned about keeping public expenditure down than left-wing governments, it is expected that finance ministries belonging to right-wing governments are more inclined to align with the budget frame (see also Pickering and Mitchell, this issue).

Proposition 2c Finance ministries that are part of right-wing governments are more likely to align with the budget frame.

\section{Methods}

The countries studied are Denmark, India, Indonesia and the USA. These countries have been selected as they represent variation on whether the finance ministry had the climate finance lead and on being, respectively, an industrialised (Annex II) or an emerging economy (non-Annex II; see Table 2). Furthermore, all of the countries have changed government, which makes it possible to study whether the political orientation of the government is influential. All four countries have played important roles in UN climate finance negotiations. Two emerging economies have been selected since the discussion of contributions from this class of countries means that they have more explicit fiscal interest in all three priorities (including whether they should contribute climate finance) than other developing countries. Consequently, the findings from India and Indonesia are relevant for other emerging economies, but not necessarily for other kinds of developing countries.

The analysis relies on a combination of key informant interviews, official documents and secondary sources. The key informants (a total of 14) were primarily senior officials currently or previously responsible for climate finance, and based in finance ministries and other key ministries (mainly environment and foreign ministries) from the countries studied. A total of nine finance ministry officials and at least two from each finance ministry were interviewed, the remaining five coming from environment and foreign affairs ministries. Four interviews were conducted with US government officials, two with Indian ones, five with Danish ones and three with Indonesian ones. The official documents comprise all documents published by the finance ministry and addressing climate finance, including reports and policy documents.

The analysis involves two stages. First, official documents and interviews have been used to identify both how climate finance is framed as a policy issue in general terms (without reference to concrete negotiation positions) by the finance ministry and which positions the finance ministry has taken on the above-mentioned key issues. ${ }^{9}$ On this basis,

9 The combination of interview and documentary data helps to corroborate evidence. 
Table 2 Country cases selected

\begin{tabular}{lll}
\hline & Industrialised & Emerging \\
\hline Finance ministry lead & USA & India \\
Finance ministry secondary role & Denmark & Indonesia \\
\hline
\end{tabular}

the finance ministry's prevalent frame (if any) is identified, as well as possible differences with other ministries. It may be methodologically difficult to distinguish the positions of finance ministries from the overall government position, especially if they are relatively similar. Second, the paper analyses whether finance ministries that had the lead, belonged to industrialised or emerging economies, or to left- or right-wing governments were more likely to use the market failure or the budget frame.

There are important challenges when it comes to studying negotiation positions, not to mention a particular ministry's position regarding the negotiation position, as these preferences maybe both very context dependent and politically sensitive. In order to address these difficulties, questions were kept on a general level and mainly focused on past issues rather than current ones.

\section{Analysis: the role of finance ministries}

This section consists of the case studies of the different finance ministries, followed by a comparison and discussion of which variables the use of frames corresponds to (see Table 3).

\subsection{USA}

The US Department of the Treasury's lead on climate finance dates back to 2008-2009 (interview with former senior US Treasury Official, 8/4/2014). Other departments and agencies involved are the White House, the State Department (which leads on UN climate negotiations generally) and to a lesser degree the Environmental Protection Agency. On the general level, the Treasury framed climate finance in terms of market failure, more specifically "as one piece of the international puzzle [...] recognising the challenges that the developing countries face, and the public good nature of mitigation especially, there is a recognition that is climate finance will be an important part" (ibid.).

Regarding the key climate finance issues, the Treasury (and the administration in general) was not in favour of targets, particularly the idea of a collective public finance target (ibid.). Following the adoption of the $\$ 100$ billion target at COP15, the US government did not want to put forward targets for its contribution of public finance (a position shared among all US officials involved in the climate talks). This was due to domestic opposition, particularly Republican scrutiny of any climate-related issue in the House of Representatives, and to it being considered less relevant than mainstreaming climate concerns into development aid and leveraging private finance (interview with former senior US Treasury official, 6/5/2014; US Department of the Treasury 2009a, 2010). Mainstreaming and leveraging were emphasised because the Treasury considered the effects of climate finance to be more important than how much the countries provide.

Regarding channels for finance, the Treasury was sceptical of the UNFCCC, which was seen as unable to provide the required economic and social safeguards or to prevent the 
Table 3 Comparison of framings, positions and lead among finance ministries

\begin{tabular}{|c|c|c|c|c|}
\hline & Denmark & India & Indonesia & USA \\
\hline $\begin{array}{l}\text { Dominant } \\
\text { framing of } \\
\text { climate } \\
\text { finance as an } \\
\text { issue }\end{array}$ & Market failure & Budget & Market failure & $\begin{array}{l}\text { Budget/market } \\
\text { failure }\end{array}$ \\
\hline \multicolumn{5}{|c|}{ Position on key issues } \\
\hline $\begin{array}{l}\text { Position on } \\
\text { targets }\end{array}$ & $\begin{array}{l}\text { Supports } \\
\text { national } \\
\text { targets; } \\
\text { national costs } \\
\text { not unfairly } \\
\text { high }\end{array}$ & $\begin{array}{l}\text { Demanding } \\
\text { targets for } \\
\text { industrialised } \\
\text { countries }\end{array}$ & $\begin{array}{l}\text { Industrialised countries } \\
\text { should adhere to their } \\
\text { targets; emerging } \\
\text { economies should also } \\
\text { contribute }\end{array}$ & $\begin{array}{l}\text { Strongly } \\
\text { opposed to } \\
\text { national } \\
\text { targets }\end{array}$ \\
\hline $\begin{array}{l}\text { Position on } \\
\text { channels }\end{array}$ & $\begin{array}{l}\text { Different } \\
\text { channels but } \\
\text { MDBs } \\
\text { important }\end{array}$ & $\begin{array}{l}\text { Green Climate } \\
\text { Fund important }\end{array}$ & $\begin{array}{l}\text { Green Climate Fund most } \\
\text { important but different } \\
\text { channels necessary }\end{array}$ & $\begin{array}{l}\text { MDBs } \\
\quad \text { important }\end{array}$ \\
\hline $\begin{array}{l}\text { Position on } \\
\text { principles }\end{array}$ & Efficiency & CBDR & Efficiency & Efficiency \\
\hline \multicolumn{5}{|c|}{ Intra- and extra-bureaucratic variables } \\
\hline $\begin{array}{l}\text { Lead ministry } \\
\text { and other } \\
\text { ministries } \\
\text { involved }\end{array}$ & $\begin{array}{l}\text { Climate, Foreign } \\
\text { Affairs, } \\
\text { Finance }\end{array}$ & $\begin{array}{l}\text { Finance, } \\
\text { Environment, } \\
\text { External } \\
\text { Affairs }\end{array}$ & $\begin{array}{l}\text { National Council on } \\
\text { Climate Change, Finance, } \\
\text { Environment }\end{array}$ & $\begin{array}{l}\text { Treasury, } \\
\text { State, White } \\
\text { House }\end{array}$ \\
\hline $\begin{array}{l}\text { Country } \\
\text { grouping }\end{array}$ & Industrialised & Developing & Developing & Industrialised \\
\hline $\begin{array}{l}\text { Change of } \\
\text { government }\end{array}$ & $\begin{array}{l}\text { Right } \\
\text { (2001-2011); } \\
\text { left } \\
(2011-2015)\end{array}$ & $\begin{array}{l}\text { Left } \\
\text { (2004-2014); } \\
\text { right (2014- } \\
\text { present) }\end{array}$ & $\begin{array}{l}\text { Centre (2004-2014); left } \\
\quad \text { (2014-present) }\end{array}$ & $\begin{array}{l}\text { Right } \\
\text { (2001-2009); } \\
\text { left (2009- } \\
\text { 2017) }\end{array}$ \\
\hline
\end{tabular}

Positions corresponding to the market failure frame are listed in italics, lead ministries are in bold

money from disappearing (interview with former senior US Treasury Official, 8/4/2014). Rather, the US Treasury preferred using existing bilateral and multilateral channels that could promote efficiency and ensure that fiduciary standards were met (US Department of the Treasury 2009b). Concerning key principles, the Treasury emphasised efficiency, particularly regarding the design of climate finance mechanisms in ways that provide as much value for money as possible (interview with former senior US Treasury Official, 8/4/ 2014). This included an important role for private finance, which was seen as crucial for an effective response to climate change, and as easing the pressure on public finance.

Altogether, there was not one specific frame which consistently underpinned the Treasury's climate finance position. While the Treasury on a general level framed climate finance in market failure terms, in terms of concrete positions it placed a greater emphasis on minimising the US contribution than one would expect from the market failure frame. Although this - especially in the case of US opposition to targets - to a large degree can be understood in terms of domestic opposition, the Treasury's positions were generally compatible with both frames. The position of the Treasury was generally shared across US 
departments and agencies, which also faced the same problem of getting climate-related legislation through Congress (interview with former senior Environmental Protection Agency and White House official, 7/4/2014).

\subsection{India}

The Indian Ministry of Finance has had the lead on climate finance since 2011, when a designated Climate Finance Unit was set-up within the Ministry. The predominant theme in how the Ministry of Finance Climate addressed climate finance was the importance of the equity principle of CBDR, as is evident in the official documents of the Indian Ministry of Finance (2009, 2012; Dasgupta and Climate Change Finance Unit 2015) as well as key informant interviews. As mentioned above, in the case of emerging economies CBDR fits with the budget frame but not the market failure frame, and in the official Ministry of Finance documents climate change is framed as an issue of justice rather than a market failure.

Regarding targets, the Ministry of Finance focused on targets for the industrialised countries while being opposed to developing country commitments to provide climate finance (Indian Ministry of Finance 2012). The Ministry of Finance particularly stressed the importance of meeting the $\$ 100$ billion target and criticised a joint OECD-Climate Policy Initiative report (2015) that argued that industrialised countries had mobilised on average $\$ 62$ billion in climate finance in 2014 (Dasgupta and Climate Change Finance Unit 2015). ${ }^{10}$ Instead the Indian Finance Ministry argued that only money disbursed (rather than just pledged or committed) from designated climate funds could be considered truly new and additional climate finance, money that totalled only $\$ 2.2$ billion since the inception of these funds. Thus, the position of the Ministry of Finance was clear-cut: the industrialised countries should be held accountable to their targets and to their commitment to provide new and additional climate finance, while the developing countries are not subject to such obligations. This position can be understood in terms of Indian commitment to CBDR (interview with senior Indian Finance Ministry official, 3/11/2014; Indian Ministry of Finance 2012) and in terms of the budget frame that pulled in the same direction.

Concerning channels for finance, the Ministry of Finance saw the Green Climate Fund as crucial since the developing countries could have a significant say in the allocation of climate finance via this Fund, unlike bilateral and private funding (Indian Ministry of Finance 2013). This position corresponds to a general preference for UN institutions (interview with senior Indian Finance Ministry official, 3/11/2014). When it comes to the key principles, besides the above-mentioned emphasis on CBDR and new and additional climate finance, the Ministry of Finance (2009) also stressed historical responsibility. Efficiency was considered important but subordinate to CBDR, e.g. leveraging private finance being considered positive as long as it does not undermine industrialised countries' public finance commitments (Indian Ministry of Finance 2013; Dasgupta and Climate Change Finance Unit 2015).

Altogether, the position of the Ministry of Finance on key issues is consistent with the emphasis on CBDR and consequently with the budget frame. The emphasis on CBDR has characterised the Indian position in the climate negotiations generally speaking (Thaker and Leiserowitz 2014) and was shared with other involved ministries such as the Environment Ministry.

${ }^{10}$ A figure that was disputed from a range of sources beyond developed country negotiators. 


\subsection{Indonesia}

The Indonesian Ministry of Finance started addressing climate finance in 2007 when it hosted the first meeting of finance ministries on climate change (in the context of COP13 in Bali). Whereas the lead on climate finance negotiation belongs to the National Council on Climate Change (DNPI), a semi-autonomous body consisting of DNPI staff and representatives of key ministries, the finance and environment ministries as well as the National Development Planning Agency (Bappenas) are the most engaged ministries regarding climate finance (Indonesian Ministry of Finance 2016).

In terms of the overarching framing of climate finance as a policy issue, the Indonesian Ministry of Finance occupied a position sharing several of the tenets of the market failure frame while emphasising CBDR. The market failure frame is evident in the Ministry of Finance's 2009 publication "Economic and Fiscal Policy Strategies for Climate Change Mitigation in Indonesia", which stresses the importance of economically sound policies and carbon pricing in Indonesia, and frames climate finance as an instrument for "covering additional investment costs and providing compensation for economic opportunity costs" (Indonesian Ministry of Finance 2009: 44). According to this publication, climate finance is necessary as developing countries account for half of global emissions and "most of the abatement options at any given level of marginal costs are in developing countries" (ibid.), a clear example of the market failure frame. The Ministry of Finance generally emphasises that a key aspect of climate finance is to send a signal to the markets, while also emphasising industrialised country responsibility and the need for international finance in Indonesia (interview with senior Indonesian Finance Ministry Official, 24/6/2015; Indonesian Ministry of Finance 2016).

Regarding targets, the Ministry of Finance has stressed the importance of industrialised country targets and particularly of meeting the $\$ 100$ billion target, including a clear pathway towards this target (interview with senior Indonesian Finance Ministry Official, 24/6/2015). The Ministry of Finance has stressed that the Indonesian government provides two-thirds of all climate finance spent in Indonesia, and while it remains willing to continue such financing, increased co-financing from industrialised countries will be essential to increasing the level of ambition (Interview with senior Indonesian official, 11/3/2015; Indonesian Ministry of Finance and Climate Policy Initiative 2014). According to this view, emerging economies should also contribute climate finance (Indonesian Ministry of Finance 2009: 62), which is why the Ministry of Finance supported Indonesia's contribution to the Green Climate Fund. Concerning channels for finance, the Ministry of Finance has stressed that the Green Climate Fund should be the primary channel of international climate finance, yet this should not eliminate the important role of bilateral climate finance (interview with senior Indonesian Finance Ministry Official, 24/6/2015). On key principles, the Ministry of Finance has stressed the importance not only of efficiency (similarly to the industrialised country finance ministries) but also of the distinction between industrialised and developing countries (Indonesian Ministry of Finance 2009; 2016), although not in as clear-cut a fashion as the Indian Ministry of Finance wants.

Altogether, in terms of finance ministerial frames the position of the Ministry of Finance is best described in terms of the market failure frame, while the budget frame-related concept of CBDR also was important. All of the involved ministries have generally been in agreement (interview with senior DNPI official, 11/12/2014). 


\subsection{Denmark}

Within the Danish government, the Ministry of Climate Change and Energy has the lead on climate finance, while the Finance Ministry and the Ministry of Foreign Affairs were closely involved in the definition of the climate finance negotiation position. The Finance Ministry has addressed climate finance since 2007, and regarding the overarching framing, climate finance was framed in terms of market failure. As global carbon pricing is not politically feasible, the primary purpose of climate finance is to correct the externality through financing mitigation actions, as part of a global mitigation system involving all aspects of developing countries' economies (interview with former senior Danish Finance Ministry official, 13/1/2014). At the same time, the Finance Ministry also sought to guard the public finances and limit spending, this being reconciled with the previous objective (correcting the externality) by focusing on using climate finance as efficiently as possible.

The Finance Ministry was in favour of collective as well as individual climate finance targets for countries. It opposed the sharp distinction between industrialised and developing countries, which it saw as outdated and counterproductive. Instead burden-sharing based on emissions and/or level of income was considered preferable (ibid.). Consequently, the Finance Ministry did not want Denmark to contribute significantly more than its fair share calculated on the basis of emissions and income. Regarding channels for finance, the Finance Ministry was somewhat sceptical of leaving too much influence with the UNFCCC institutions, and preferred using a range of channels including MDBs and bilateral finance. Concerning the key principles, efficiency has been considered crucial and mainly understood in global and far-sighted terms.

Within the Danish government, the Finance Ministry's emphasis on avoiding excessively high contributions and its scepticism towards the UNFCCC at times put it at odds with the climate and the foreign affairs ministries. The latter ministries wanted higher levels of climate finance than the Finance Ministry and were more positive towards the UNFCCC. The position of the Finance Ministry itself was rather consistently based on the market failure frame, although the budget frame is evident regarding targets and channels for finance.

\subsection{Comparisons}

The analysis has shown that the positions of finance ministries on specific priorities in the negotiations mainly clustered around specific frames, thus largely supporting Proposition 1. Hence, a finance ministry that framed climate finance as a solution to a market failure and was willing to contribute climate finance also tended to support MDBs as a finance channel and efficiency as a key principle. Yet, there are examples of dissonance, e.g. the US Treasury, which on an overarching level defined climate finance in market failure terms but adopted specific positions more in line with the budget frame. In the case of the Danish and Indonesian finance ministries, the market failure frames were clearly prevalent, although the budget frame also was observable. The position of the Indian Ministry of Finance is better understood in terms of the budget frame due to its CBDR emphasis.

Regarding the correspondence between having the lead and a particular frame, it appears that the Indonesian and Danish finance ministries — which did not have the leadadopted positions more in line with the market failure frame than the Indian and US finance ministries, both of which had the lead, thus failing to confirm Proposition 2a. This alignment across the industrialised/developing countries fault line also partly fails to 
confirm Proposition $2 \mathrm{~b}$, although the notable similarities between India and Indonesia (particularly their emphasis on CBDR), to some degree supports the proposition.

On Proposition 2c (right-wing governments corresponding with use of the budget frame), some of the countries changed government from right-wing to left-wing (Denmark in 2011, the USA in 2009), from centre to left-wing (Indonesia in 2014) or from left-wing to right-wing (India in 2014; Denmark in 2015) during the period of analysis. Yet, the proposition is not supported as it is only in the USA that this change of government corresponds with significant changes in the finance ministry position towards a more market failure frame-oriented position. The USA change from the Bush administration to the Obama administration constituted a major shift in both domestic climate policy and climate negotiation positions. This shift is largely due to climate change being highly politicised in the USA (McCright and Dunlap 2011), but also due to the high level of change in government personnel following US elections. In both respects-particularly the latter-the US must be considered a most-likely case for changes in government being important. Thus, it is only possible to generalise from the case of the USA to other countries in which climate change is equally politically salient (see also Pickering and Mitchell, this issue).

\section{Conclusion}

The positions of most finance ministries in the present paper mainly clustered around one of two frames: the market failure frame or the budget frame. Ministries aligning with the former defined climate finance as a way of addressing the market failure of climate change, while ministries aligning with the latter defined climate finance as budget expenditure to be limited. The market failure frame was mainly important to the Danish and Indonesian finance ministries' position, and the budget frame mainly to the US and particularly the Indian ones. Thus, to a large degree the budget frame corresponded with the finance ministry having the lead on climate finance and the market failure frame with the finance ministry not having the lead. The use of the two frames criss-crossed the divide between industrialised and emerging economies - although not regarding CBDR - while the frames have not changed when the government did, except for in the USA.

The market failure frame was-in the industrialised economies-an important requirement for finance ministries' acknowledging the importance of climate finance (mainly mitigation finance). This capacity for taking the issue seriously does not imply less fragmentation within the climate finance system. The finance ministries did not converge around one frame, something which could have reduced normative and institutional fragmentation, especially if the frame had been that of market failure.

The fact that it was the finance ministries with lead roles that subscribed most strongly to the budget frame, potentially leading to more self-interested positions, arguably constitutes a domestic cause of increased norm fragmentation. Yet, the convergence between the Indonesian and Danish finance ministries indicates that the market failure frame opens up possibilities for alignment between finance ministries from industrialised and emerging economies. Such convergence is arguably based on shared epistemic outlooks based on training as economists. The fact that the US and Indian finance ministry officials also shared such a background indicates that it constitutes a necessary rather than sufficient condition for convergence. These findings indicate that strengthening forums and epistemic communities for finance ministry representatives and built around the market failure frame 
can be a fruitful venue for reducing norm fragmentation, but the success of such forums will depend on their ability to overcome domestic forces pulling in the direction of the budget frame. Furthermore, to the extent that these forums exist outside the UNFCCC, such forums will increase institutional fragmentation.

There remains a need for further research the causal role of these frames, specifically whether frames as underlying structures of belief actually influenced the finance ministerial position, as the consistency between each ministry's position on the different issues suggests. It is also worth exploring the degree to which the frames influenced the national negotiation positions. It is also useful to study how finance ministries treat climate issues that do not involve expenditure, for instance fossil fuel subsidy reform, or to focus on the role of finance ministries regarding the delivery of climate finance.

Acknowledgements Earlier versions of this paper were presented at the 2015 Lund Climate Finance Workshop and the 2015 Annual Convention of the International Studies Association. The author would particularly like to thank Jonathan Pickering, Carola Betzold, Tobias Böhmelt, Pieter Pauw, the three anonymous reviewers and the participants in the Lund Climate Finance Workshop for their extremely useful comments and suggestions at the various stages of writing and revising this paper.

Funding The research for this article was undertaken as part of the project "International Economic Institutions and Domestic Actors in the Climate Regime Complex", which has been funded by the Swedish Research Council [Vetenskapsrådet], the Bank of Sweden Tercentenary Foundation [Riksbankens Jubileumsfond] the Swedish Research Council Formas [Forskningsrådet Formas].

Open Access This article is distributed under the terms of the Creative Commons Attribution 4.0 International License (http://creativecommons.org/licenses/by/4.0/), which permits unrestricted use, distribution, and reproduction in any medium, provided you give appropriate credit to the original author(s) and the source, provide a link to the Creative Commons license, and indicate if changes were made.

\section{References}

Allison, G., \& Zelikow, P. (1999). Essence of decision: Explaining the Cuban missile crisis (2nd ed.). New York: Longman.

Bailer, S., \& Weiler, F. (2015). A political economy of positions in climate change negotiations: Economic, structural, domestic, and strategic explanations. Review of International Organizations, 10(1), 43-66.

Ciplet, D., Robert, J. T., \& Khan, M. (2013). The politics of international climate adaptation funding: Justice and divisions in the greenhouse. Global Environmental Politics, 13(1), 49-68.

Dasgupta, D., \& Climate Finance Unit. (2015). Climate change finance, analysis of a recent OECD report: Some credible facts needed. Delhi: Indian Ministry of Finance.

Dellink, R., den Elzen, M., Aiking, H., Bergsma, E., Berkhout, F., Dekker, T., et al. (2009). Sharing the burden of financing adaptation to climate change. Global Environmental Change, 19(4), 411-421.

Downie, C. (2014). The politics of climate change negotiations. Cheltenham, UK: Edward Elgar.

Haites, E. (Ed.). (2014). International climate finance. London: Routledge.

Halimanjaya, A., \& Papyrakis, E. (2012). Donor characteristics and the supply of climate change aid. School of International Development, Working Paper 42. Norwich, UK: University of East Anglia.

Harrison, K., \& Sundstrom, L. M. (2007). The comparative politics of climate change. Global Environmental Politics, 7(4), 1-18.

Hof, A. F., den Elzen, M. G. J., \& Mendoza Beltran, A. (2011). Predictability, equitability and adequacy of post-2012 international climate financing proposals. Environmental Science \& Policy, 14, 615-627.

Indian Ministry of Finance (2009). Climate change and India-Some major issues and policy implications. Indian Ministry of Finance (2012). Brief on Climate Change Finance.

Indian Ministry of Finance (2013). Delhi vision statement: The Green Climate Fund.

Indonesian Ministry of Finance. (2009). Ministry of finance green paper: Economic and fiscal policy strategies for climate change mitigation in Indonesia. Jakarta: Ministry of Finance and Australia Indonesia Partnership. 
Indonesian Ministry of Finance (2016). Sustainable development finance. http://www.fiskal.kemenkeu.go. id/pkppim/en/. Accessed 1 Oct 2016.

Indonesian Ministry of Finance and Climate Policy Initiative. (2014). The landscape of public climate finance in Indonesia. Jakarta: Indonesian Ministry of Finance.

Jacobs, M. (1997). Sustainability and markets: On the neoclassical model of environmental economics. New Political Economy, 2(3), 365-385.

Kaarbo, J. (1998). Power politics in foreign policy: The influence of bureaucratic minorities. European Journal of International Relations, 4(1), 67-97.

Kanbur, R. (2001). Economic policy, distribution and poverty: The nature of disagrements. World Development, 29(6), 1083-1094.

Kingdon, J. W. (2003). Agendas, alternatives and public policies. London: Longman.

McCright, A. M., \& Dunlap, R. E. (2011). The politicization of climate change and polarization in the American public's views of global warming, 2001-2010. Sociological Quarterly, 52(2), 155-194.

Michaelowa, A. (Ed.). (2012). Carbon markets or climate finance? Low carbon and adaptation investment choices for the developing world. London: Routledge.

Michaelowa, A., \& Michaelowa, K. (2011). Coding error or statistical embellishment? The political economy of reporting climate aid. World Development, 39(11), 2010-2020.

Moore, F. C. (2012). Negotiating adaptation: Norm selection and hybridization in international climate negotiations. Global Environmental Politics, 12(4), 30-48.

Moravcsik, A. (1998). The choice for Europe. Social purpose and state power from Messina to Maastricht. London: UCL Press.

OECD and Climate Policy Initiative. (2015). Climate finance in 2013-14 and the USD 100 billion goal. Paris: OECD.

Persson, A., \& Remling, E. (2014). Equity and efficiency in adaptation finance: Initial experiences of the adaptation fund. Climate Policy, 14(4), 488-506.

Pickering, J., Skovgaard, J., Kim, S., Roberts, J. T., Rossati, D., Stadelmann, M., et al. (2015). Acting on climate finance pledges: Inter-agency dynamics and relationships with aid in contributor states. World Development, 68, 149-162.

Pralle, S. B. (2009). Agenda-setting and climate change. Environmental Politics, 18(5), 781-799.

Raustiala, K., \& Victor, D. G. (2004). The regime complex for plant genetic resources. International Organization, 58(2), 277-309.

Schön, D. A., \& Rein, M. (1994). Frame reflection: Toward the resolution of intractable policy controversies. New York: Basic Books.

Seabrooke, L. (2011). Economists and diplomacy: Professions and the practice of economic policy. International Journal: Canada's Journal of Global Policy Analysis, 66(3), 629-642.

Skovgaard, J. (2012). Learning about climate change: Finance ministries in international climate change politics. Global Environmental Politics, 12(4), 1-8.

Skovgaard, J. (2015). Greener than expected? EU finance ministries address climate finance. Environmental Politics, 24(6), 951-969.

Stadelmann, M., Persson, Å., Ratajczak-Juszko, I., \& Michaelowa, A. (2014). Equity and cost-effectiveness of multilateral adaptation finance: Are they friends or foes? International Environmental Agreements, 14(2), 101-120.

Stern, N. (2006). The economics of climate change: The Stern review. Cambridge: Cambridge University Press.

Stern, D.I., Jotzo, F., \& Dobes, L. (2013). The economics of global climate change: A historical literature review. CCEP Working Paper 1307, November 2013. Crawford School of Public Policy, The Australian National University.

Thaker, J., \& Leiserowitz, A. (2014). Shifting discourses of climate change in India. Climatic Change, 123, $107-119$.

UNFCCC (1992). United Nations Framework Convention on Climate Change. Document number FCCC/ IMFORMAL/84.

UNFCCC (2009). Decision 2/CP.15. Copenhagen accord. Document FCCC/CP/2009/11/Add.1.

UNFCCC (2010). Decision 1/CP.16. Cancún agreements. Document FCCC/CP/2010/7/Add.1.

UNFCCC (2015). Decision 1/CP.21. Paris agreement. Document FCCC/CP/2015/10/Add.1.

US Department of the Treasury (2009a). Secretary of the Treasury Timothy F. Geithner. Written Testimony before the Senate Foreign Relations Committee 17 November 2009.

US Department of the Treasury (2009b). FY 2009 report congress on the environment multilateral development banks. 
US Department of the Treasury (2010). Testimony of Lael Brainard Under Secretary of the Treasury for International Affairs Before the Subcommittee on Asia, the Pacific and the Global Environment, United States House of Representatives, July 27, 2010.

Wildavsky, A. (1986). Budgeting: A comparative theory of budgetary processes (2nd ed.). New Brunswick, NJ: Transaction Books. 